\title{
Opvattingen over het maatschappelijke belang van religie
}

Jacques Janssen, Joris Kregting \& Ton Bernts

\section{Inleiding en vraagstelling}

Hoe de maatschappelijke rol van de religie in de Nederlandse geschiedenis meerdere malen radicaal verschoven is, heeft Van Rooden (1996) pregnant beschreven. Vanaf de aanvang van de Republiek, zoals ook in het ontstaan ervan, was de religie van centrale betekenis, steeds onder monopolie van de gereformeerde kerk. Zolang de anderen, met name de katholieken, die hegemonie en de ermee gepaard gaande discriminatie niet ter discussie stelden, was er sprake van een grote mate van vrijheid en wederzijdse religieuze erkenning. In de Franse tijd wordt de scheiding tussen kerk en staat een onomkeerbaar feit. Het vaderland wordt voortaan geschraagd door een band tussen morele burgers waarbij het protestantse karakter overigens dominant blijft.

Tot de zeventiger jaren van de $19^{\mathrm{e}}$ eeuw was bijna elke Nederlander lid van een kerk. Daarna is er sprake van een snelle opmerkelijke teruggang van de hervormde kerk en een voor Europese begrippen opvallende groei van het aantal niet-kerkleden (Kruyt, 1933). Het meest opmerkelijk is het ontstaan vanuit gereformeerde en katholieke kring van de verzuilde samenleving. De religie boet tot in de jaren zeventig van de 20e eeuw nauwelijks aan betekenis in. De natie wordt gedragen door zuilen: samenlevingen binnen de samenleving.

Pas vanaf ongeveer 1970 is wederom sprake van een abrupte en totale omslag. In enkele jaren tijd groeit het aantal niet-kerkleden spectaculair. De religieuze gelijkenis tussen de Nederlanders neemt met sprongen toe: "binnen één generatie is de natie weer de hoogste morele gemeenschap voor de Nederlanders geworden. Als fundamenteel geschiedverhaal dat uitlegt waar Nederland over gaat, is de Opstand vervangen door de Tweede Wereldoorlog" (Van Rooden, 1996, p. 44).

Van Roodens conclusies zijn intrigerend, maar erg globaal. Ze verdienen enige relativering en een nadere toespitsing. Enerzijds zijn de maatschappelijke effecten van de klassieke kerkelijke religie nog steeds aantoonbaar. De zuilen wankelen en zijn afgeknot, maar als restanten van een roemrucht verleden en tegen de achtergrond van een vergruisde samenleving steken ze er duidelijk uit. Uit hedendaags onderzoek blijkt bovendien dat de klassieke religievariabelen wel degelijk van invloed zijn op maatschappelijke gedrag en met name de bereidheid om vrijwilligerswerk te doen (Dekker \& De Hart, 
2002). Anderzijds heeft Van Rooden nauwelijks oog voor de opkomende geïndividualiseerde religiositeit. Dat het niet gaat om een oppervlakkig modeverschijnsel, maar een typisch Nederlands fenomeen verdient nadere uitleg. Het seculariseringsproces is voornamelijk een West-Europees verschijnsel en binnen West-Europa heeft Nederland al sinds enkele decennia een koppositie. Het aantal kerkleden is nergens zo snel gedaald en zo laag (Halman, 2001). Ook onderzoek onder jongeren wijst in deze richting (Campiche, 1997). Toekomstprognoses voorspellen een grote meerderheid van buitenkerkelijken. Onderzoek (Kregting en Sanders, 2003) roept het beeld op van een natie die over twintig jaar voor 70\% uit buitenkerkelijken bestaat. De rest van de Nederlandse samenleving wordt dan gevormd door katholieken, protestanten en islamieten; alledrie de groepen ongeveer gelijk van omvang. Hoe betrouwbaar dergelijke prognoses zijn, zal moeten blijken en niemand kan met zekerheid in de toekomst zien. Als we ons tot het heden beperken, blijkt de zaak al ingewikkeld genoeg. Zo mag men op basis van de eerder gemelde gegevens niet zonder meer conclusies trekken inzake de individuele religiositeit van de Nederlander. Dat de 'fallacy of the wrong level' in werkelijkheid en niet alleen in handboeken bestaat, blijkt hier eens te meer. Op zich lijkt het aannemelijk dat kerklidmaatschap en individuele religiositeit, bijvoorbeeld de mate waarin men bidt, hand in hand gaan. De feiten wijzen daar ook op. In de Europese landen is er een hoge samenhang tussen het aantal kerkleden en het percentage mensen dat bidt (Halman, 2001). Maar twee landen wijken beduidend af van deze trend. In Denemarken is per traditie een overgrote meerderheid lid van de Lutherse kerk, het percentage mensen dat bidt is opmerkelijk laag. Voor Nederland geldt de omgekeerde situatie: weinig kerkleden en veel bidders. Ook zitten er op zondag aanmerkelijk meer Nederlanders in de kerk dan Denen. Nederlandse jongeren vertonen de hoogste graad van onkerkelijkheid: ons land is zestiende in een rij van zestien landen. Baseren we ons echter op religieuze activiteit, en met name bidden, dan belanden we op de derde plaats: achter Italië en Ierland (Campiche, 1997, p. 52). In de European Values Study (Halman, 2001, p. 74 en 97) blijkt dit ook in zijn algemeenheid te gelden: weer zijn we zestiende en laatste wat kerklidmaatschap betreft; tiende wat kerkbezoek betreft; vijfde wat betreft het bidden: terwijl $46 \%$ van de Nederlanders zich kerklid noemt, zegt $71 \%$ te bidden. In nationaal en lokaal onderzoek wordt vastgesteld dat er ook buiten kerkelijk verband sprake is van vormen van religiositeit. Met name is geconstateerd, in twee onafhankelijke onderzoekingen, dat de correlatie tussen mysticisme (een korte samenvatting van de klassieke schaal van Stacey en Hood) en kerklidmaatschap naar nul tendeert. Gevoelens van transcendentie en verheven gelukzaligheid zijn binnen en buiten de kerken gelijkelijk verdeeld (Janssen, 2002; Te Grotenhuis en Scheepers, 2001). 
Kortom, Nederland past bij uitstek in de door Davie (1994) aangegeven trend van 'believing without belonging' (zie ook Halman, Luijkx, Van Zundert 2005, p. 72). Terwijl Anton van Duinkerken meer parochianen dan gelovigen om zich heen zag, lijkt de situatie inmiddels omgekeerd. Het aantal kerkleden daalt naar een ongekend minimum, maar veel Nederlanders geloven in spirituele en hogere zaken en blijven individueel actief op religieus gebied. De vraag die zich opdringt, is of de geïndividualiseerde religiositeit een functioneel alternatief kan zijn voor de klassieke, kerkgebonden religiositeit, of dat het maatschappelijk effect van religie verdampt in het totale proces van individualisering.

\section{Vraagstelling}

In dit artikel staan twee onderzoeksvragen centraal:

- Hoe denkt de Nederlandse bevolking over het maatschappelijke belang van religie?

- Heeft religie behalve in zijn tanende, institutionele, historische vorm ook als opkomend geïndividualiseerd verschijnsel een positieve invloed op het maatschappelijk belang dat mensen toekennen aan religie?

\section{Theoretische en empirische achtergronden: de toekenning van maatschappelijke relevantie aan religie}

$\mathrm{Al}$ eerder is gesteld dat er steeds meer Nederlanders zijn die zich niet meer rekenen tot een religieuze groepering. De ontkerkelijking van de afgelopen decennia heeft ertoe geleid dat in 2002 bijna tweederde van de Nederlandse bevolking als 'buitenkerkelijk' kan worden betiteld (SCP, 2003). In deze periode viel ook waar te nemen dat religie steeds meer maatschappelijk 'onzichtbaar' is geworden. De privatiseringthese (Luckman, 1967) is in Nederland al diverse malen aangetoond: religie beperkt zich meer en meer tot de privé-sfeer en verliest allerlei traditionele sociale en publieke functies. Zuilen zijn grotendeels verdwenen en religieuze instituten drukken nog maar nauwelijks hun stempel op bijvoorbeeld de politiek, de media en de economie.

Ontkerkelijking en religieuze privatisering zijn twee seculariseringprocessen die de verwachting oproepen dat Nederlanders het belang van religie voor de samenleving niet meer zo groot zullen vinden. Het onderzoek God in Nederland (Dekker, De Hart \& Peters, 1997) heeft laten zien dat dit in 1996 (nog) niet het geval was. Een groot deel van de Nederlanders (ook degenen die geen lid waren van een kerk- of geloofsgemeenschap) vond toen dat er in de samenleving nog steeds een rol was weggelegd voor de kerken. Kerken fungeerden volgens veel Nederlanders als betrouwbare informatiebronnen voor belangrijke maatschappelijke en politieke vraagstukken, ze bescherm- 
den de samenleving tegen egoïsme en verval van het moraal en ze dienden zich uit te spreken over sociale achterstelling en discriminatie. Bernts (2003) komt enkele jaren later tot soortgelijke conclusies.

Voor veel Nederlanders geldt, blijkens het onderzoek God in Nederland, dat ze erg gesteld zijn op persoonlijke vrijheden, ook als het om geloofsbeleving gaat. Dit conflicteert met een nauwe verbondenheid aan religieuze instituten en heeft eraan bijgedragen dat het merendeel van de bevolking buitenkerkelijk is (geworden). Dit betekent echter niet dat zij de maatschappelijke relevantie van religie uitvlakken.

\section{Kerkelijke betrokkenheid en religiositeit}

Kerkelijke betrokkenheid en religiositeit zijn twee belangrijke factoren ter verklaring van de opvattingen over het maatschappelijke belang van religie. Kerkelijke betrokkenheid staat hierbij voor de band met een geloofsgemeenschap, dat wil zeggen lidmaatschap en actieve betrokkenheid. Religiositeit geeft aan of men gelooft in God of een hogere macht.

Vanuit de eerdere bevindingen dat een toename van de buitenkerkelijkheid niet automatisch leidt tot een vermindering van de toekenning van het belang van religie voor de samenleving (Dekker et al, 1997), verwachten we dat veel Nederlanders religie nog steeds belangrijk vinden voor de Nederlandse samenleving. We verwachten dat de mate van religiositeit (zowel geinstitutionaliseerd als niet-geïnstitutionaliseerd) daarbij bepalend is.

\section{Hypothese 1}

Gelovige Nederlanders, of ze nu wel of geen lid zijn van een kerk, vinden religie belangrijker voor de maatschappij dan niet-gelovige Nederlanders.

\section{De mening over de kwaliteit van de kerken}

De verklaring van de opvattingen over het maatschappelijke belang van religie op basis van kerkelijke betrokkenheid en religiositeit wordt gecontroleerd voor de perceptie en houding ten aanzien van kerkelijke instituties. We verwachten dat deze beoordeling van de kwaliteit van de kerken een intermediërende werking heeft en de invloed van kerkelijke betrokkenheid en religiositeit op de opvattingen over het maatschappelijke belang van religie voor een deel zal 'wegverklaren'.

Indien er een effect is van kerkelijke betrokkenheid, dan zou dit deels kunnen komen doordat kerkleden (kerkgaand of niet-kerkgaand) de kwaliteit van de kerkelijke instituties hoog inschatten en daarom religie belangrijk vinden voor de samenleving. Met betrekking tot religiositeit kan vergelijkbaar worden geredeneerd: het is mogelijk dat gelovigen positiever over de kwaliteit van de kerk oordelen, dan niet-gelovigen, en dat gelovigen hierdoor meer belang toekennen aan de rol van religie voor de samenleving. 


\section{Hypothese 2a}

Kerkleden (kerkgaand en niet-kerkgaand) vinden het maatschappelijke belang van religie groter dan niet-kerkleden omdat ze positiever zijn over de kwaliteit van de kerken.

\section{Hypothese 2b}

Gelovige Nederlanders vinden het maatschappelijke belang van religie groter dan niet-gelovige Nederlanders omdat ze positiever zijn over de kwaliteit van de kerken.

Het verklarende model zal verder worden gecontroleerd voor de achtergrondvariabelen geslacht, leeftijd en opleiding. Vereenvoudigd weergegeven komt het model er als volgt uit te zien:

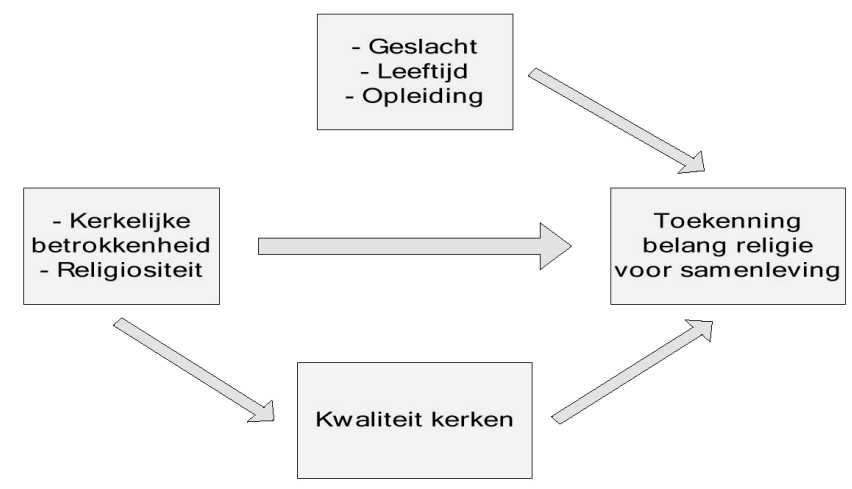

\section{Data en operationalisering}

\section{Data}

In het voorjaar van 2003 is onder 312 Nederlanders van 18 jaar en ouder een publieksonderzoek gehouden, door middel van telefonische interviews. Deze steekproef is na bijweging representatief wat betreft geslacht, leeftijd, opleiding en regio. Aan de respondenten zijn vragen voorgelegd over de kerkelijke achtergrond, de aard en rol van religie in het persoonlijke leven, de perceptie en waardering van kerkelijke instituties, het belang van religie voor de samenleving en de mogelijke rol van de overheid bij religie en kerken.

\section{Afhankelijke variabele}

In tabel 1 wordt weergegeven hoe het belang van religie voor de Nederlandse samenleving is bevraagd. Uit een factoranalyse is gebleken dat de twaalf vragen tot een schaal geconstrueerd kunnen worden; deze schaal geeft weer hoe belangrijk Nederlanders de rol van religie voor de samenleving vinden. Bijna tweederde van de Nederlanders (64\%) vindt religie enigszins of heel belangrijk voor de maatschappij. 
Tabel 1: Het belang van religie voor de maatschappij (in \%; $\mathrm{n}=312$ )

\begin{tabular}{l|lll|l}
\hline Hoe belangrijk vindt men religie: & $\begin{array}{l}\text { heel } \\
\text { belang- } \\
\text { rijk }\end{array}$ & $\begin{array}{l}\text { enigszins } \\
\text { belang- } \\
\text { rijk }\end{array}$ & $\begin{array}{l}\text { niet } \\
\text { belang- } \\
\text { rijk }\end{array}$ & $\begin{array}{l}\text { *factor } \\
\text { scores }\end{array}$ \\
\hline & & & & \\
bij levensmomenten als geboorte en overlijden & 43 & 27 & 30 & 0,829 \\
voor het behoud van waarden en normen & 39 & 33 & 28 & 0,719 \\
bij de opvoeding van kinderen & 35 & 40 & 25 & 0,723 \\
bij rampen & 28 & 35 & 37 & 0,771 \\
om ons voor te houden hoe we goed moeten & & & & \\
samenleven & 28 & 33 & 39 & 0,807 \\
bij herdenkingen & 24 & 46 & 30 & 0,720 \\
voor het wijzen op maatschappelijke misstanden & 22 & 34 & 44 & 0,792 \\
voor onze identiteit als Europeaan & 20 & 28 & 52 & 0,847 \\
voor onze identiteit als Nederlander & 19 & 35 & 46 & 0,792 \\
om te wijzen op het belang van soberheid & 17 & 32 & 51 & 0,660 \\
bij nationale feestelijkheden & 14 & 38 & 48 & 0,577 \\
om een luis in de pels te zijn van de machtheb- & & & & \\
bers & 14 & 26 & 60 & 0,664 \\
\hline & & & & \\
schaal 'belang religie voor Nederlandse samenle- & & & & \\
ving* & 16 & 48 & 36 & \\
\hline
\end{tabular}

* Principale Componenten Analyse, Varimax-methode met proportie verklaarde variantie van $55,6 \%$. Cronbach's Alpha is 0,93 .

In de analyse wordt de afhankelijke variabele 'belang religie voor de samenleving' verklaard door acht onafhankelijke en intermediërende variabelen:

- Geslacht. Man of vrouw, waarbij vrouwen de referentiecategorie vormen.

- Leeftijd. Leeftijd in jaren (variërend van 18 tot en met 90 jaar). Deze variabele is als intervalvariabele in de analyse opgenomen.

- Opleidingsniveau. De hoogst genoten, afgeronde, opleiding van de respondenten. De onderscheiden categorieën zijn: lager onderwijs (1), lbo (2), mavo (3), mbo (4), havo of vwo (5), hbo (6) en wo (7). Deze variabele is als intervalvariabele in de analyse opgenomen.

- Kerklidmaatschap. De kerk of geloofsgemeenschap waartoe men zich rekent valt uiteen in vier categorieën (dummy's): rooms-katholieken, protestanten (Nederlands-hervormd of gereformeerd), leden van een andere kerk of geloofsgemeenschap en onkerkelijken. Deze categorieën worden als dummy's opgenomen in de analyse waarbij de onkerkelijken als referentiecategorie dienen.

- Kerkgang. De frequentie van het bezoeken van een kerk of andere godsdienstige bijeenkomst. Deze variabele bevat de categorieën nooit (1), en- 
kele keren per jaar (2), gemiddeld één keer per maand (3) en (bijna) elke week (4) en is als intervalvariabele opgenomen in de analyse.

- Religiositeit. Respondenten zijn 'gelovig' als ze geloven dat er een God is die zich met ieder mens persoonlijk bezighoudt of geloven dat er iets moet zijn als een hogere macht die het leven beheerst. Respondenten die niet weten of er een God of hogere macht bestaat worden als 'agnost' getypeerd, respondenten die het bestaan van God of een hogere macht ontkennen als 'atheïst' De drie categorieën zijn als dummy's in de analyse opgenomen waarbij 'gelovigen' als referentiecategorie fungeert.

- Kwaliteit van de kerken. Respondenten hebben gereageerd op twaalf stellingen over de perceptie en houding ten aanzien van kerkelijke instituties (zie Bijlage A). Met elf van de twaalf stellingen is, na een factoranalyse, een schaal geconstrueerd ${ }^{1}$ die de kwaliteit van de kerken weergeeft. Respondenten zijn positief over deze kwaliteit, neutraal of negatief. De variabele is als intervalvariabele in de analyse opgenomen met scores oplopend van negatief (1) naar positief (5).

De onafhankelijke en intermediërende variabelen worden afzonderlijk op hun verklarend vermogen getoetst. Dit houdt in dat per variabele wordt gecontroleerd voor invloeden van andere variabelen.

\section{Analyse en resultaten}

Nederlanders en de maatschappelijke relevantie van religie

Niet alle Nederlanders vinden religie even belangrijk voor de maatschappij (tabel 2). Laag en middelbaar opgeleiden en 'ouderen' (van zestig jaar en ouder) vinden religie belangrijker voor de samenleving dan hoog opgeleiden en Nederlanders onder de zestig jaar.

Bij onderscheid naar kerklidmaatschap, kerkgang en religiositeit worden de verschillen groter. Kerkleden (vooral de protestanten) en Nederlanders die geregeld naar de kerk gaan, vinden de maatschappelijke relevantie van religie veel groter dan respectievelijk de Nederlanders die niet tot een kerk- of geloofsgemeenschap horen en zelden of nooit naar de kerk gaan. Mensen die geloven in het bestaan van God of een hogere macht vinden religie belangrijker dan mensen die hierin niet geloven of hieraan twijfelen.

Mensen die de kerken positief beoordelen, vinden de maatschappelijke relevantie van religie groot. Daartegenover staat dat geen enkele Nederlander die negatief is over de kwaliteit van de kerken, religie belangrijk vindt voor de samenleving. 
Tabel 2: Belang van religie voor de samenleving (in \%)

\begin{tabular}{|c|c|c|c|c|}
\hline & belangrijk & $\begin{array}{l}\text { enigszins } \\
\text { belangrijk }\end{array}$ & $\begin{array}{l}\text { niet } \\
\text { belangrijk }\end{array}$ & $n$ \\
\hline Totaal & 16 & 48 & 36 & 311 \\
\hline \multicolumn{5}{|l|}{ Geslacht } \\
\hline man & 17 & 50 & 33 & 151 \\
\hline vrouw & 15 & 47 & 38 & 159 \\
\hline \multicolumn{5}{|l|}{ Opleiding* } \\
\hline laag & 23 & 47 & 30 & 90 \\
\hline midden & 15 & 50 & 35 & 136 \\
\hline hoog & 7 & 49 & 44 & 84 \\
\hline \multicolumn{5}{|l|}{ Leeftijd* } \\
\hline tot 30 jaar & 3 & 58 & 39 & 62 \\
\hline 30-45 jaar & 17 & 40 & 43 & 100 \\
\hline 45-60 jaar & 12 & 45 & 43 & 83 \\
\hline 60 jaar en ouder & 30 & 58 & 12 & 66 \\
\hline \multicolumn{5}{|l|}{ Kerklidmaatschap* } \\
\hline protestant & 47 & 51 & 2 & 47 \\
\hline rooms-katholiek & 18 & 76 & 6 & 49 \\
\hline ander kerk-/geloofsgenootschap & 35 & 61 & 4 & 23 \\
\hline geen & 5 & 40 & 55 & 192 \\
\hline \multicolumn{5}{|l|}{ Kerkgang* } \\
\hline (bijna) elke week & 46 & 43 & 11 & 54 \\
\hline gemiddeld één keer per maand & 28 & 72 & 0 & 25 \\
\hline enkele keren per jaar & 10 & 60 & 30 & 78 \\
\hline nooit & 6 & 41 & 53 & 154 \\
\hline \multicolumn{5}{|l|}{ Religiositeit* } \\
\hline gelovig & 25 & 51 & 24 & 173 \\
\hline agnost & 2 & 52 & 46 & 88 \\
\hline atheïst & 8 & 31 & 60 & 48 \\
\hline \multicolumn{5}{|l|}{ Kwaliteit kerken* } \\
\hline positief & 37 & 51 & 12 & 51 \\
\hline neutraal & 15 & 51 & 34 & 194 \\
\hline negatief & 0 & 38 & 62 & 53 \\
\hline \multicolumn{5}{|l|}{ Politieke voorkeur* } \\
\hline CDA & 33 & 47 & 20 & 51 \\
\hline PvdA & 11 & 47 & 42 & 79 \\
\hline VVD & 4 & 45 & 51 & 45 \\
\hline Groen Links en SP & 4 & 59 & 37 & 27 \\
\hline D66 & 0 & 54 & 46 & 13 \\
\hline ChristenUnie en SGP & 78 & 17 & 5 & 18 \\
\hline
\end{tabular}

* Verschil tussen de groepen is significant $(\mathrm{p}<.05)$ 
Wat betreft de politieke voorkeur ${ }^{2}$ blijkt dat de Nederlanders die op christelijke partijen stemmen, CDA en vooral ChristenUnie en SGP, religie belangrijk vinden voor de samenleving. De Nederlanders die een andere voorkeur hebben, vinden religie hooguit enigszins belangrijk maar toch ook bijna even vaak onbelangrijk.

Het maatschappelijke belang van religie, naar kerkelijke betrokkenheid

Voorafgaand aan de regressieanalyse waarin de invloed van de kenmerken uit tabel 3 op de toekenning van de maatschappelijke relevantie van religie afzonderlijk worden opgenomen, wordt een eerste aanzet voor de verklaring gegeven door kerklidmaatschap, kerkgang en religiositeit ${ }^{3}$ te combineren. De vier typen die op basis van deze 'mate van kerkelijke betrokkenheid' ontstaan, zijn:

- Kernleden: mensen die lid zijn van een kerk of geloofsgemeenschap, minimaal één keer per maand een kerkdienst of andere godsdienstige bijeenkomst bezoeken en geloven in God of een hogere macht.

- Randleden: mensen die in God of een hogere macht geloven, lid zijn van een kerk of geloofsgemeenschap, maar zelden of nooit een kerkdienst of andere godsdienstige bijeenkomst bezoeken.

- Gelovige niet-kerkleden: mensen die geen lid zijn van een kerk of geloofsgemeenschap (en dus ook zelden of nooit een kerk of andere godsdienstige bijeenkomst bezoeken) maar wel geloven in God of een hogere macht.

- Niet-gelovige niet-kerkleden: mensen die geen lid zijn van een kerk of geloofsgemeenschap (en dus zelden of nooit een kerkdienst of andere godsdienstige geloofsgemeenschap bezoeken) en niet geloven in God of een hogere macht.

Tabel 3 geeft weer in hoeverre bovenstaande groepen religie relevant achten voor de maatschappij.

Tabel 3: Opvattingen over het maatschappelijke belang van religie, naar kerkelijke betrok-

\begin{tabular}{|c|c|c|c|c|}
\hline & belangrijk & $\begin{array}{l}\text { enigszins } \\
\text { belangrijk }\end{array}$ & $\begin{array}{l}\text { niet } \\
\text { belangrijk }\end{array}$ & $n$ \\
\hline kernlid & 44 & 53 & 3 & 73 \\
\hline randlid & 13 & 76 & 11 & 37 \\
\hline gelovige niet-kerkleden & 6 & 48 & 46 & 79 \\
\hline niet-gelovige niet-kerkleden & 4 & 38 & 58 & 109 \\
\hline totaal & 16 & 48 & 36 & 311 \\
\hline
\end{tabular}

* Verschil tussen de groepen is significant $(\mathrm{p}<.05)$ 
Bijna alle kernleden vinden religie tenminste enigszins belangrijk voor de samenleving. Dit geldt in iets mindere mate ook voor de randleden. Onder de gelovige niet-kerkleden vindt $46 \%$ religie niet maatschappelijk relevant; onder de niet-gelovige niet-kerkleden is dit deel nog iets groter, namelijk $58 \%$.

Deze tweedeling, tussen kerkleden (kern- en randleden) enerzijds en niet-kerkleden (gelovig en niet-gelovig) anderzijds, duidt op een sterke invloed van kerklidmaatschap op de opvattingen over het maatschappelijke belang van religie.

De tweedeling ten aanzien van de maatschappelijke relevantie van religie komt overeen met de tweedeling bij het doen van vrijwilligerswerk en in iets mindere mate bij het geven van geld aan goede doelen (Bijlage B, tabel B1 en B2). Kerkleden doen meer vrijwilligerswerk dan niet-kerkleden en geven ook wat vaker geld aan goede doelen.

De grote invloed van de sociale achtergrond, waaronder kerklidmaatschap, op het geven van geld aan goede doelen en het doen van vrijwilligerswerk zien we ook in ander onderzoek terug. Bekkers (2004) laat zien dat dit soort gedrag veel beter wordt voorspeld door de sociale kenmerken kerkgang en 'religieuze socialisatie' dan door persoonlijkheidskenmerken zoals geloofsopvattingen.

Ook de waardering van de kwaliteit van de kerken (Bijlage B, tabel B3) kent in grote lijnen hetzelfde patroon als dat van de opvattingen over het maatschappelijke belang van religie: kerkleden aan de ene kant (zij vinden de kwaliteit van kerken zelden slecht) en niet-kerkleden aan de andere kant (ruim een kwart van hen vindt de kwaliteit slecht).

\section{Verklaring van de opvattingen over het maatschappelijke belang van religie}

Middels een stapsgewijze meervoudige regressieanalyse wordt weergegeven welke factoren een rol spelen in het belang dat Nederlanders aan religie toekennen voor het functioneren van een samenleving. Allereerst worden de effecten getoetst van de achtergrondkenmerken en religiositeit (tabel 4, model 1 en 2), daarna wordt kerklidmaatschap en kerkgang toegevoegd (model 3) en tenslotte de intermediërende variabele kwaliteit van de kerken (model 4).

Uit de eerste twee modellen komt naar voren dat vrouwen meer maatschappelijke relevantie aan religie toekennen dan mannen, oudere meer dan jongere Nederlanders en gelovigen meer dan agnosten en atheïsten. Dit komt overeen met de gegevens uit tabel 4 . Het opleidingsniveau heeft geen effect op het toegekende belang van religie voor de samenleving. De verschillen tussen de opleidingsniveaus uit tabel 4 verdwijnen wanneer er wordt gecontroleerd voor leeftijd.

Model 3 laat zien dat rooms-katholieken, protestanten en leden van andere kerk- of geloofsgemeenschappen religie belangrijker vinden voor de 
maatschappij dan de Nederlanders die geen lid zijn van een kerk of geloofsgemeenschap.

De significante invloeden van model 1 en 2 verdwijnen met de opname van kerklidmaatschap en kerkgang (model 3). Deze variabelen spelen een intermediërende rol tussen religiositeit en de toekenning van het belang van religie voor de maatschappij. Dit houdt in dat gelovige Nederlanders niet meer belang hechten aan religie voor de maatschappij dan niet-gelovigen, tenzij zij (actief) lid zijn van een kerkgemeenschap. Hypothese 1 wordt hiermee gefalsificeerd.

In model 4 wordt als intermediërende variabele de kwaliteit van de kerken opgenomen. Uit een afzonderlijke analyse (Bijlage C) blijkt dat protestantse kerkleden een positiever beeld hebben over de kwaliteit van de kerken dan niet-kerkleden (en dan rooms-katholieke kerkleden en leden van andere kerken $)^{4}$. Hoewel de opvattingen over de kwaliteit van de kerken een redelijke invloed hebben op de opvattingen over het maatschappelijke belang van religie, zorgt de opname van deze (veronderstelde) intermediërende variabele er niet voor dat het effect van kerklidmaatschap (en dan met name van de protestantse kerkleden) sterk daalt. Geconcludeerd kan worden dat kerkleden religie belangrijker vinden voor de maatschappij dan niet-kerkleden, zonder dat dit kan worden verklaard door de bevinding dat kerkleden veel positiever zijn over de kwaliteit van de kerken dan niet-kerkleden.

Tabel 4: De determinanten van de opvattingen van het maatschappelijke belang van religie (gestandaardiseerde bèta-coëff. en proportie verklaarde variantie; $\mathrm{n}=297$ )

\begin{tabular}{|c|c|c|c|c|c|c|c|}
\hline & & Model 1 & Model 2 & Model 3 & & Model 4 & \\
\hline \multicolumn{2}{|c|}{ geslacht (vrouw =ref.) } & 0,063 & $0,125 *$ & 0,073 & & 0,048 & \\
\hline \multicolumn{2}{|l|}{ leeftijd } & $0,217 \approx *$ & $0,152 * *$ & 0,065 & & 0,081 & \\
\hline \multicolumn{2}{|l|}{ opleiding } & $-0,079$ & $-0,076$ & $-0,070$ & & $-0,076$ & \\
\hline \multirow[t]{3}{*}{ religiositeit } & gelovig & & ref. & ref. & & ref. & \\
\hline & agnost & & $-0,230 * *$ & 0,007 & & $-0,014$ & \\
\hline & atheïst & & $-0,290 * *$ & $-0,058$ & & $-0,063$ & \\
\hline \multirow[t]{4}{*}{ kerklidmaatschap } & $\begin{array}{l}\text { niet-kerklid } \\
\text { rooms- }\end{array}$ & & & ref. & & ref. & \\
\hline & katholiek & & & 0,230 & $* *$ & 0,223 & $* *$ \\
\hline & protestant & & & 0,389 & $* *$ & 0,343 & $* *$ \\
\hline & lid andere kerk & & & 0,211 & $* *$ & 0,195 & $* *$ \\
\hline kerkgang & & & & 0,139 & $*$ & 0,086 & \\
\hline kwaliteit kerken & & & & & & 0,169 & $* *$ \\
\hline $\mathrm{R}^{2}$ & & 0,065 & 0,159 & 0,349 & & 0,371 & \\
\hline
\end{tabular}

$* \mathrm{p}<0,05 ; * * \mathrm{p}<0,01$ 
Ook het bezoeken van kerkelijke vieringen versterkt de toekenning van het belang van religie voor de maatschappij. Deze invloed verdwijnt echter met de opname van de kwaliteit van de kerken. Nederlanders die geregeld naar de kerk gaan, hebben een positieve houding over de kerk (Bijlage C) en vinden religie daardoor voor de maatschappij relevant.

Met betrekking tot religiositeit wordt hypothese $2 \mathrm{~b}$ gefalsifieerd: de beoordeling van de kwaliteit van de kerken speelt geen intermediërende rol. Deze beoordeling speelt ook geen intermediërende rol bij niet-kerkgaande kerkleden, maar wel bij kerkgaande kerkleden (hypothese 2a wordt deels geverifieerd).

\section{Samenvatting en conclusie}

In het actuele normen- en waardendebat wordt veelal verondersteld dat de sociale cohesie in de Nederlandse samenleving onder druk is komen te staan. Individualisering- en seculariseringprocessen zouden hieraan ten grondslag liggen. Ter bevordering van de onderlinge betrokkenheid onder burgers menen bepaalde beleidsmakers en opinieleiders dat religie weer een prominentere rol moet gaan spelen. In dit artikel is niet nagegaan in hoeverre het sociaal kapitaal van de Nederlandse samenleving de afgelopen decennia daadwerkelijk onder druk is komen te staan; andere onderzoeken geven aan dat dit enigszins gerelativeerd dient te worden. Er is wel nagegaan wat Nederlanders vinden van het maatschappelijke belang van religie. Bijna tweederde van de Nederlanders vindt religie tenminste enigszins belangrijk voor de samenleving. Leden van kerkgenootschappen vinden religie bijna allemaal van belang. Protestanten lopen hierbij voorop, gevolgd door katholieken en leden van andere kerkgenootschappen. Onder de Nederlanders die geen lid zijn van een kerk- of geloofsgemeenschap zijn de meningen verdeeld en is de toekenning van het belang aan religie het geringst: ongeveer de helft vindt het enigszins van belang, de andere helft vindt het niet van belang.

De opvattingen over het maatschappelijke belang van religie blijkt na een regressieanalyse af te hangen van kerklidmaatschap, en niet van religiositeit. De invloed van het geloof, verdwijnt wanneer rekening wordt gehouden met kerklidmaatschap: gelovige Nederlanders achten religie niet belangrijker voor de samenleving dan niet-gelovigen, tenzij de gelovigen zijn verbonden aan een religieus instituut. Actieve betrokkenheid binnen een kerk, door het bezoeken van kerkelijke vieringen, zorgt daarnaast nog voor een positieve houding ten aanzien de kwaliteit van de kerken en daardoor ook indirect voor het belangrijk vinden van religie voor de samenleving.

Tegen onze verwachting in heeft religiositeit op de toekenning van het belang van religie nauwelijks effect. Ook onder onkerkelijken heeft religiosi- 
teit geen additioneel effect, gelovige onkerkelijken vinden religie niet belangrijker dan agnostische of atheïstische onkerkelijken. Individuele religiositeit blijkt hiermee geen functioneel alternatief voor institutionele religiositeit als het gaat om het belang dat Nederlanders toekennen aan de rol van religie in hun maatschappij. Hierdoor zal de individuele religiositeit ook slechts een marginale rol spelen als bron van sociaal kapitaal die de vorming van een nationaal verband genereert.

Een kantekening bij de beperkte rol van religiositeit betreft de door ons gehanteerde definitie hiervan. De indeling op basis van het geloof in God of een hogere macht is tamelijk rigoureus in een tijd dat vormen van geloof en spiritualiteit vaak sterk zijn geïndividualiseerd en aldus diffuus van aard zijn.

De invloed van kerklidmaatschap op de toekenning van het belang van religie voor de samenleving kan voor de nabije toekomst consequenties hebben, gezien het grote aantal randleden van de kerkgenootschappen. Prognoses (SCP, 2000) gaan uit van een verdere daling van het aantal kerkleden, in ieder geval tot 2010. Met name onder randleden zal een generatie-effect waarneembaar zijn: kinderen van randleden zullen zich vaak als onkerkelijk beschouwen. Met deze voortzetting van het seculariseringproces zal de totale steun voor religie op het niveau van de samenleving afnemen.

Een werkzame factor om dit proces tegen te gaan vormt de kwaliteit van de kerken. Onder onkerkelijken worden de opvattingen over het maatschappelijke belang van religie namelijk niet bepaald door religiositeit, maar wel in sterke mate door de mening over de kwaliteit van de kerken. Kerken worden uitgedaagd kwaliteit te leveren, zowel wat betreft de feitelijke activiteiten als de profilering naar de buitenwereld.

\section{Literatuur}

Bekkers, R.H.F.P. (2004). Giving and volunteering in the Netherlands: sociological and psychological perpectives.

Bernts, T. (2003). Boodschap aan de kerken? Zoetermeer: Meinema.

Campiche, R. (Ed.) (1997). Cultures des jeunes et religions en Europe. Parijs : les éditions du Cerf.

Davie. G. (1994). Religion in Britain since 1945: believing without belonging. Oxford: Blackwell.

Dekker, P., Hart, J. de (2002). Het zout der aarde: een analyse van de samenhang tussen godsdienstigheid en sociaal kapitaal in Nederland. Sociale Wetenschappen 45 (1):45-61.

Dekker, P., Hart, J. de \& Peeters, J. (1997). God in Nederland 1966-1996. Amsterdam: Anthos.

Grotenhuis, te M. \& Scheepers, P. (2001) Kerken kenteren in de keizerstad. De religieuze en levensbeschouwelijke kaart van Nijmegen aan het einde van de 20e eeuw. Nijmegen: Mediagroep. 
Halman, L. (2001). The European values study: A third wave. Tilburg: Tilburg University/ WORC/EVS.

Halman, L., Luijkx, R., Zundert, M. van (2005). Atlas of European values. Tilburg: Tilburg University.

Janssen, J. (2002). Aan de onbekende God. Reiken naar religie in een geseculariseerde cultuur. Nijmegen: SUN.

Kregting, J. \& Sanders, J. (2003). 'Waar moeten ze het zoeken?' Vindplaatsen van religie en zingeving bij jongvolwassenen. Nijmegen: KASKI.

Kruijt, J. (1933). De onkerkelikheid in Nederland: haar verbreiding en oorzaken: proeve ener sociografiese verklaring. Groningen: Noordhoff.

Luckman, T. (1967). The invisible religion: the problem of religion in modern society. New York: Macmillan.

Rooden, P. van (1996). Religieuze regimes : over godsdienst en maatschappij in Nederland 1570-1990. Amsterdam: Bakker.

Sociaal Cultureel Planbureau (2000). Secularisering in de jaren negentig. Rijswijk: Sociaal en Cultureel Planbureau.

Sociaal Cultureel Planbureau (2003). De vaststelling van kerkelijke gezindtes in enquêtes: $40 \%$ of $60 \%$ buitenkerkelijken? Rijswijk: Sociaal en Cultureel Planbureau.

\section{Noten}

1 Cronbach's Alpha is $0,76$.

2 De politieke voorkeur wordt naar verwachting beïnvloed door de mate waarin men religie van belang acht voor de samenleving, en niet andersom. Om deze reden is dit kenmerk in de verdere analyse achterwege gelaten.

3 Agnosten (mensen die niet weten of er een God of hogere macht bestaat) zijn op basis van de extra vraag of men zich wel of niet als een gelovig mens beschouwt, ingedeeld in 'gelovig' en 'niet-gelovig'.

${ }^{4}$ Uit een extra analyse blijkt dat er geen interactie-effect tussen de onafhankelijke variabelen kwaliteit kerken en kerklidmaatschap. Het effect van de kwaliteit van de kerken op de opvattingen over de maatschappelijke relevantie van religie, verschilt dus niet naar kerkgenootschap. Er is ook geen interactie-effect tussen de variabelen kerklidmaatschap en religiositeit. 


\section{Bijlage A: Stellingen over de kwaliteit van de kerkelijke instituties}

De kerken in Nederland:

- zeggen zinnige dingen over de wereldpolitiek;

- bemoeien zich te veel met allerlei dingen;

- zijn modern en staan open voor deze tijd;

- geven goede antwoorden op spirituele vragen en behoeftes van mensen;

- zeggen zinnige dingen over euthanasie;

- hebben bekwame priesters of dominees in dienst;

- hebben ook niet-gelovigen iets te bieden;

- zijn hopeloos ouderwets;

- zeggen zinnige dingen over de sociale problemen in ons land;

- zijn er toch altijd op uit om je te bekeren;

- kunnen ons veel leren;

- maken de waarde van bijbel en evangelie duidelijk.

$\mathrm{Na}$ een factoranalyse blijkt dat er, met uitzondering van de stelling 'de kerken in Nederland zijn er toch altijd op uit om je te bekeren' een schaal geconstrueerd kan worden. Hierbij zijn de antwoordcategorieën van de stellingen 'de kerken in Nederland bemoeien zich teveel met allerlei dingen' en 'de kerken in Nederland zijn hopeloos ouderwets' omgedraaid. De proportie verklaarde variantie van de schaal is $29,9 \%$, alle stellingen hebben factorscores van 0,45 of meer. 


\section{Bijlage B: Tabellen op basis van kerkbetrokkenheid}

Tabel B1: Geld aan goede doelen* (in \%)

\begin{tabular}{l|ccc|c}
\hline & & & (bijna) & \\
& regelmatig & soms & nooit & $n$ \\
\hline & & & & \\
kernlid & 74 & 26 & 0 & 73 \\
randlid & 73 & 19 & 8 & 37 \\
gelovige niet-kerkleden & 60 & 31 & 9 & 80 \\
niet-gelovige niet-kerkleden & 48 & 36 & 16 & 111 \\
\hline & & & & \\
totaal & 59 & 31 & 10 & 312 \\
\hline
\end{tabular}

*Verschil tussen de groepen is significant $(\mathrm{p}<.05)$

Tabel B2: Vrijwilligerswerk, aantal uren per maand* (in \%)

\begin{tabular}{|c|c|c|c|c|c|c|}
\hline & & inder da & & $20 u u r$ & & \\
\hline & geen & $10 \mathrm{uur}$ & 10-20 uur & of meer & gemiddeld & $n$ \\
\hline kernlid & 42 & 27 & 23 & 8 & 6,7 & 73 \\
\hline randlid & 56 & 25 & 6 & 14 & 8,4 & 37 \\
\hline $\begin{array}{l}\text { gelovige niet-kerkleden } \\
\text { niet-gelovige }\end{array}$ & 65 & 19 & 7 & 9 & 4,8 & 80 \\
\hline niet-kerkleden & 62 & 24 & 10 & 4 & 4,7 & 111 \\
\hline totaal & 57 & 24 & 11 & 8 & 5,5 & 312 \\
\hline
\end{tabular}

*Verschil tussen de groepen is significant $(\mathrm{p}<.05)$

Tabel B3: Kwaliteit kerken* (in \%)

\begin{tabular}{l|ccc|c}
\hline & goed & redelijk & slecht & $n$ \\
\hline & & & & \\
kernlid & 41 & 55 & 4 & 73 \\
randlid & 6 & 91 & 3 & 35 \\
gelovige niet-kerkleden & 7 & 63 & 30 & 78 \\
niet-gelovige niet-kerkleden & 11 & 63 & 26 & 104 \\
\hline & & & & \\
totaal & 17 & 65 & 18 & 299 \\
\hline
\end{tabular}

* Verschil tussen de groepen is significant $(\mathrm{p}<.05)$ 


\section{Bijlage C: Kwaliteit van de kerken}

Van de variabele kwaliteit van de kerken wordt verondersteld dat deze een intermediërende invloed heeft tussen de onafhankelijke variabelen en de toekenning van het belang van religie voor de samenleving. In de tabel C1 wordt weergegeven in hoeverre geslacht, leeftijd, opleiding, religiositeit, kerklidmaatschap en kerkgang de intermediërende variabele beïnvloeden.

Tabel C1: De determinanten van de instemming van de kwaliteit van de kerken (gestandaardiseerde bèta-coëfficiënten en proportie verklaarde variantie)

\begin{tabular}{ll|lll}
\hline & & Model 1 & Model 2 & Model 3 \\
\hline \multirow{2}{*}{$\begin{array}{l}\text { geslacht }(\mathrm{man}=1) \\
\text { leeftijd }\end{array}$} & $0,147 *$ & $0,182 * *$ & $0,140 *$ \\
opleiding & & 0,009 & $-0,018$ & $-0,088$ \\
religiositeit & gelovig & 0,032 & 0,032 & 0,036 \\
& agnost & & ref. & ref. \\
& atheïst & & $-0,100$ & $0,125 *$ \\
Kerk- & & & $-0,175 * *$ & 0,045 \\
lidmaatschap & onkerkelijk & & & \\
& rooms-katholiek & & & ref. \\
& protestant & & & 0,045 \\
& lid andere kerk & & & $0,276 * *$ \\
kerkgang & & & & 0,093 \\
$\mathrm{R}^{2}$ & & & & $0,313 * *$ \\
\hline
\end{tabular}

$* \mathrm{p}<0,05 ; * * \mathrm{p}<0,01$

Met betrekking tot de kwaliteit van de kerken zijn mannen en agnosten positiever dan respectievelijk vrouwen en gelovigen. De belangrijkste determinanten zijn echter kerklidmaatschap en kerkgang. Protestanten zijn positiever over de kwaliteit van de kerken dan onkerkelijken. Katholieken en leden van andere kerken verschillen opvallend genoeg niet van de onkerkelijken als het gaat hun mening over de kwaliteit van de kerken. Tenslotte hebben mensen die geregeld naar de kerk gaan een positievere mening over die kerk dan mensen die minder vaak of nooit gaan. 